\title{
Sultan II. Murad Devrine Ait Aruz Konulu Bir Eser: Mutahhar B. Ebî Tâlib'in Ravzatu'l-Evzân'ı
}

\author{
Üzeyir ASLAN*
}

Öz

Ravzatu'l-Evzân, Sultan II. Murad döneminde Mutahhar b. Ebî Tâlib-i Lârendî tarafından nazmedilmiş aruz konulu bir eserdir. Şair hakkında kaynaklarda hiçbir bilgi bulunmamaktadır. Türkiye Yazma Eserler Kurumu'nun kayıtlarına göre bahse konu bu eseri dışında onun Miftâh-ı Edeb isimli bir sözlüğü de bulunmaktadır. Ravzatu'l-Evzân iki bölümden oluşur. Mukaddimenin yer aldığı ilk bölüm beyitler hâlinde, vezinlerin anlatıldığı ikinci bölüm ise dörtlükler hâlinde düzenlenmiştir. İlk bölümde şair eserinin adını verir ve onu kim için nazmettiğini belirtir. Buradaki bilgilere göre eser Mustafa Bey’e ithaf edilmiştir. Mustafa Bey, Karamanoğlu II. Mehmed Bey’in oğlu olmalıdır. Şair devamında aruz vezinlerini meydana getiren aslî rükünler, fer'ler ve bahirler hakkında bilgi verir. İkinci bölümde ise yirmi dört vezin anlatılmaktadır. Metinde hâtime bölümü bulunmamaktadır. Biz eserin iki yazma nüshasını tespit ettik, her iki nüshayı karşılaştırarak çeviriyazılı ve tenkitli bir metin ortaya koyduk, ilaveten metni bugünkü Türkçeye aktardık. Yine eserde anlatılan aruz vezinlerini 15. ve 16. yüzyıllarda aynı konuda telif edilmiş başka eserlerle mukayese ettik.

Anahtar Kelimeler: Aruz, Bahr, Vezin, Ravzatu'l-Evzân, Mutahhar, Karamanoğlu Mustafa Bey.

\footnotetext{
* Prof. Dr., Marmara Üniversitesi, Fen-Edebiyat Fakültesi, Türk Dili ve Edebiyatı Bölümü, İstanbul, Türkiye. Elmek: uaslan@marmara.edu.tr https://orcid.org/0000-0002-8478-4580.
} 


\title{
A Book is About Prosody Written in Period of Sultan Murad The Second: Ravzāt al-Avzōan By Mutahhar b. Abī Tālib
}

\begin{abstract}
Ravzatu'l-Evzân is a work on Arabic prosody written by Mutahhar b. Ebî Tâlib-i Lârendî during the period of Ottoman Sultan Murad II. There is no information about the poet in the sources. However, according to the records of the Manuscript Institution of Turkey, apart from this work, he also has an Arabic-Persian dictionary named Miftâh-l Edeb. Ravzatu'l-Evzân consists of two parts. The first part, where the introduction (mukaddime) takes place, is written in couplets and the second part, where the prosodies are explained, is written in verses. In the first part, the poet tells the name of his work and who he has written it for. According to the information given here, the book was dedicated to Mustafa Bey, the son of Karamanid Mehmed Bey II. Then the poet gives information about the fundamental elements of aruz prosodies. Twenty four prosodies are explained in the second part. The work does not have an epilogue. We found two manuscript copies of the book and by comparing them, we produced a translated and critical text. We also translated it into today's Turkish. Furthermore, we compared the aruz prosody explained in the work with other copyrighted works on the same subject in the 15 th and 16 th centuries.
\end{abstract}

Keywords: Prosody, Meter, Ravzatu’l-Evzân, Mutahhar, Karamanid Mustafa Bey. 


\section{Extended Summary}

Arud is a prosdy from Arabic literature, it was systematized by Imām Halīl b. Ahmad (d. 791) who was one of the Arabian linguist and scholar in Makka. Arud prosody becomes widespread other muslim countries and their literature, like Persian and Turkish. There are some books which teach arud in Arabic, Persian and Turkish. The first books about this subject are al-Mufaddal al-Dabbī (d. 786)'s Kitāb al-Arūd and Halīl b. Ahmad's three books were named Kitāb al-Arūd, Kitāb al-Misāl min al-Arūd and Kitāb al-Farsh fì al-Arūd in Arabic literature. In Persian literature Umar al-Rāduyān̄̄'s Tarcamān al-Balāga written in 12th century and Rashīd al-dīn-i Vatvat (d. 1177)'s Risāla-i Arūd are first books about this. In Anatolia where written like these books that Ahmad-i Gulshehrī (d. 1317)'s Arūd, Ahmadī (d. 1413)'s Ilm-i Arūd and Risāla fī alArūd, Ahmad-i Dā‘̄̄i (d. 1421)'s Ilm-i Arūd and also Mutahhar b. Abī Tālib alLārandī (d. 1423?)'s Ravzat al-Avzān.

Arud has eight base elements, fa'ūlun, fācilun, mafā'îlun, mustaf'ilun, fācilātun, mufā'alatun, mutafā'ilun and maf'̄ūātu. These elements produce nineteen classes of metres which are named țavīl, madīd, basīṭ, vāfir, kāmil, mutaḳārib, mutadārik, hazac, racaz, ramal, sarī̄, munsariḥ, hafīf, mużāric, muḳtaḍab, muctes, cadīd, ḳarīb, mushākil with some variations. Some classes unique to Arabic, like tavīl, madīd, basīṭ, vāfir and kāmil; some of them unique to Persian which are cadīd, ḳarīb, mushākil but Arabics don’t use Persian's classes of metres, except for these are communal in Arabic and Persian literature. Turkish poets prefer Persian metres. The classes produce five schedules of metres arranged in circular form.

Ravzatu'l-Evzân is a work on Arabic prosody written by Mutahhar b. Ebî Tâlib-i Lârendî during the period of Ottoman Sultan Murad II. There is no information about the poet in the sources. Nihad M. Çetin says that Mutahhar wrote an other book in 1416, but he doesn't inform about it and thus we don't know about this book. However, according to the records of the Manuscript Institution of Turkey, apart from this work, he also has an Arabic-Persian dictionary named 
Miftâh-ı Edeb. According to the catalog in Gazi Husrev Begova Libary in Sarajevo, this book is a dictionary from Persian to Turkish, but unfortunately it doesn't have any information about Mutahhar b. Abi Talib al-Larandi. Ravzatu'l-Evzân consists of two parts. The first part, is the introduction (mukaddime) written in couplets, and here, the poet tells the name of his work and who he has written it for. According to the information given here, the book was dedicated to Mustafa Bey, the son of Karamanid Mehmed Bey II. This part has twenty two couplets. The second part contains twenty four prosodies written in quatrain form. These meters are: bahrr-i racaz-i mațvī muftacilun muftacilun fầcilun baḥr-i munsarị̣-i mațvī / baḥr-i racaz-i bā-ziḥāf u ḥashv muftacilun fācilun muftacilun fa', baḥr-i

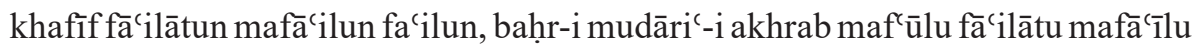

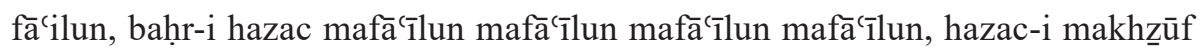

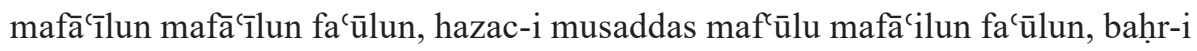

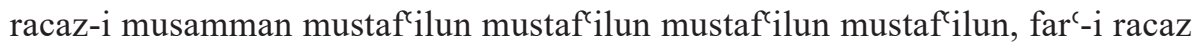
mufta'ilun $\mathrm{fa}^{\prime}$ mufta'ilun $\mathrm{fa}^{c}$, far'-i racaz $\mathrm{fa}^{\prime}$ mufta'ilun mufta'ilun mufta'ilun $\mathrm{fa}^{\mathrm{c}}$, far'-i racaz fa` mufta'ilun mafā'ilun fac', racaz-i sālim / basīṭ u hazac-i mulamma` muftacilun mafācilun muftacilun mafācilun, baḥr-i nav'-i ākhar az-racaz-i ziḥāf fa' muftacilun fa'lun fa' mufta'ilun fa'lun, baḥr-i vāfir mufā'alatun mufă'alatun mufācalatun, baḥr-i kāmil mutafācilun mutafăcilun mutafācilun mutafācilun, far'-i kāmil mutafăcilun mutafācilun mutafācilun, far'-i kāmil mutafăcilun facūlun mutafācilun facūlun, baḥr-i mutaḳārib facūlun fa'c̄lun facūlun fa'cul, baḥr-i basīṭ mufta'ilun fācilun mufta'ilun făcilun, far'-i basīt mustaf ${ }^{\prime} i l u n$ fa ${ }^{\prime}$ ūlun mustaf ${ }^{\prime} i l u n$ facūlun, baḥr-i ramal făcilātun fācilātun fācilātun făcilun, ramal-i maḳṣūr fācilātun fācilātun făcilun, ramal-i makhbūn facilātun facilātun facilātun facilun. The work does not have an epilogue or a conclusion part. We found two manuscript copies of book, compared them and did a critical edition, also translated it into today's Turkish. Additionally, we compared it with the other prosody books such as Ahmadī’s Risāla fì al-Arūd, Ahmad-i Dā ‘’̀̀s Ilm-i Arūd, Alī b. Husayn al-Amāsī (d. 1471)'s Risāla min al-Arūz, Bardakhī (d. 1500?)'s Risāla al-Arūz and Surūrī (d. 1562)'s Bahr al-Ma 'ārif. 


\section{Giriş}

Arapça bir sözcük olan 'arûż (<'-r-ż), Mekke ve Medine ile bu iki şehrin civarı, acemi ve vahşi dişi deve, nahiye, bir dağın yakınından geçen daracık yol, sözün manası, yolcunun aniden önüne çıkan mekân, çok nesne, aniden çıkan bulut, taâm, çalı ve dikenlikte otlayan koyun ve keçi, engel ve ihtiyaç, (MÜTERCIM ÂSIM EFENDİ, 2013, s. 3014) çadırın orta direği, cihet, taraf ve yön (ÇETIN, 1991, s. 424) anlamlarına gelir. Edebî kavram olarak ise şiir ölçüsü, ölçülü ile ölçüsüz şiiri birbirinden ayırmaya yarayan şey, İmām el-Ḩalīl b. Aḥmed (öl. 175/791)'in Mekke'de sistemleştirdiği aruz ilmi, vezin bilgisi, bir kasidenin başlangıç beytinin ilk mısraı, herhangi bir beytin ilk mısraı (ÇETIN, 1991, s. 425) ve bir beytin ilk misraının son cüzünü ifade eder. (MÜTERCİM ÂSIM EFENDİ, 2013, s. 3014-3015) Sözcüğün terim anlamının hangi sözlük anlamından oluştuğu ise kesin değildir. (ÇETİN, 1991, s. 425)

Aruz ölçüsü Arap edebiyatında ortaya çıkmış, oradan Fars ve Türk edebiyatlarına geçmiştir. Aruz, Arap harflerinin harekeli veya sakin oluşuna dayanmaktadır. Bu harekeli ve sakin harfler çeşitli şekillerde bir araya gelerek sebeb, veted ve fasıla denilen biçimleri; bu biçimler de efâ'îl ü tefâ'îl, evzân u mevâzîn denilen temel aruz rükünlerini (cüz, tef'ile) oluşturur. Bunlar fe'ūlün, fācilün, mefấc̄ilün, müstef'ilün, fā́cilātün, müfā'aletün, mütefā'ilün ve mef'ūlātü'dür. Bu rükünler bazen aslî biçimlerini koruyarak bazen de zahf edilerek (ç. zihâf, değiştirme) bir araya getirilir; böylece aruz vezinleri oluşur. Aruz vezinlerinin oluşumundaki benzerlik veya farklılıklar bahirleri ortaya çıkarmıştır. Bu bahirler şunlardır: țavīl, medīd, basīṭ, vāfir, kāmil, müteḳārib, mütedārik, hezec, recez, remel, serī‘, münseriḥ, hafif, mużāric, muḳtẹ̣ab, müctes , cedīd, ḳarīb, müşākil. Bunlardan țavīl, medīd, basịṭ, vāfir ve kāmil bahirleri Arap edebiyatına mahsustur. Cedīd, ḳarīb ve müşākil ise Fars edebiyatına mahsustur; Araplar bu bahirlerde şiir söylemezler. Geriye kalan on bir 
bahir ortaktır. Bahirler de daireleri (beş daire) oluşturmuştur. (ÇETİN, 1991, s. 427-428)

Arap edebiyatında el-Mufażżal el-Żabbī (öl. 170/786)'nin Kitābu'l'Arūż'u ve İmām el-Ḩalīl b. Aḥmed'in Kitābu'l-'Arūù, Kitābu'l-Misāl mine'l'Arüż ve Kitābu'l-Ferşs fi'l-'Arüż'u (ÇETIN, 1991, s. 426) aruz konusunda yazılmış ilk eserlerdir. ${ }^{1}$

Arap edebiyatından Fars edebiyatına geçen aruz, yeni bahirler icat edilerek (cedīd, ḳarīb ve müşākil bahirleri) kısmen de olsa özgün bir biçimde Fars şiirinde esas ölçü olmaya devam etmiştir. (TAŞ, 2000, s. 4) Fars edebiyatında aruza dair yazılan ilk eserler 'Umar er-Rāduyānī'nin Tercumānu'l-Belāàa's1 (12. yy.), Nizāāī-yi ‘Arūżı̄’nin Çehār Maḳāle’si (12. yy.) ve Reşīduddīn-i Vatvat (öl. 573/1177)'1n Risāle-yi 'Arüż'udur. (ÇETiN, 1991, s. 431)

Anadolu'da yazılan aruz konulu en eski eser Aḥmed-i Gülşehrī (öl. 717/1317)'nin Farsça kaleme aldığı 'Arüż'udur. Bu eserin bilinen tek yazma nüshası Millet Kütüpanesi Ali Emiri Farsça Yazmaları nr. 517'de bulunmaktadır. Daha sonra yazılan Aḥmedī (öl. 815/1413)'nin Farsça İlm-i ‘Arūż’u Süleymaniye Kütüphanesi Şazeli Tekkesi Bölümü nr. 147, 239-246 ${ }^{\text {b' }}$ de, şairin Türkçe telif ettiği Risāletun fì'l-'Arüż'u ise Berlin Devlet Kütüphanesi'de Ms. or. oct. 3744 numarada kayıtlı mecmuanın 144 $-147^{\mathrm{a}}$ yaprakları arasındadır. Ahmedî'nin çağdaşı Ahmed-i Dā̄î̀ (öl. 824/1421)'nin 'ỉlm-i 'Arūż u (SEVGİ, 2007) ve bu çalışmanın da konusu olan Muțahhar b. Ebī Țālib-i Lārendī (öl. 826/1423?)'nin Ravżatu 'l-Evzān'ı aruza dair nazmedilmiş ilk Türkçe eserlerdendir. ${ }^{2}$

\section{Aruz Konulu Bazı Türkçe Risâleler}

Ravzatu'l-Evzân'in aruz risâleleri arasındaki yerini tespit maksadıyla aynı konuda yazılmış bazı Türkçe eserler üzerinde durmak istiyoruz.

1 Arap edebiyatında aruz konusu ilgili ayrıntılı bilgi için bk. (ÖZDEMIR, 2015)

2 Aruz konusunda yazılmış başka Türkçe eserler için bk. (TAŞ, 2000, s. 6-17) Aruza dair bir bibliyografya çalışması için bk. (BELENKUYU, 2020) 
Bildiğimiz kadarıyla aruz konulu en eski Türkçe eser Ahmedî’nin Risâletun fi'l- 'Arûz'udur. Bu küçük risâle doğrudan vezinlerle başlamakta, bahrin ismi ve fer'i yazıldıktan sonra bir beyit örnek verilmekte ve takti'i gösterilmektedir. Risâlede altı vezin, örneği ve takti'i ile birlikte anlatılmaktadır.

Ahmed-i Dâ'î'nin 'İlm-i 'Arûz'u 29 aruz vezninin kıt'alar hâlinde birer örnekle açılanmasından ibarettir. (SEVGİ, 2007)

Alî b. Hüseyn-i Amâsî (öl. 875/1471)'nin Risâletun mine'l- 'Arûz ve Istılâhi'ş-Şi ' $r$ 'i hamdele, salvele ve sebeb-i telif bölümleri ile başlamakta, devamında aruz, şiir, beyt, mısra, mesnevi vb. şiir 1stılahları, aruzun sekiz aslî rüknü ile 16 bahr ve takti' kuralları hakkında bilgi verilmekte, sonrasında 33 vezin birer Türkçe ve Farsça beyitle açıklanmaktadır. (COŞKUN, 2003)

Bardahî (öl. 905/1500?)'nin Türkçe ve Farsça Manzum Aruz Risalesi'nde aruz, cüzleri ve takti' ine dair bilgiler verildikten sonra 33 vezin Türkçe kıt'alar ve birer Farsça beyitle izah edilmektedir. (SEVGİ, 2008)

Sürûrî (öl. 969/1562)'nin Bahru'l-Me 'ârif'i hamdele, salvele ve sebeb-i telif bölümleri ile başlamakta, devamında aruz, sebeb, veted, fasıla ve takti' hakkında bilgi verilmekte, sonrasında 19 aslî bahir ve illetleri ile birlikte 45 vezin tanıtılmaktadır. (ŞAFAK, 1991)

Aşkî (öl. 999/1590?)'nin 'Arûsu'l-'Arûz'unda hamdele, salvele ve sebeb-i telif bölümleri bulunmakta, devamında aruzun sözlük ve sstılah anlamları, sekiz aslî rükün, sebeb, veted ve fasıla hakkında bilgiler verilmektedir. Vezinlerin açıklandığı birinci bölümde 19 aslî bahir, ikinci bölümde ise şairin kendisinin oluşturduğu vezinler kıt'alar hâlinde tanıtılmaktadır. Eserde hâşiyeler de bulunmaktadır. (YAZAR, 2014)

\subsection{Mutahhar b. Ebî Tâlib-i Lârendî ve Ravzatu'l-Evzân'ı}

Ravzatu'l-Evzân'ın şairi Mutahhar'ın hayatı hakkında kaynaklarda hiçbir bilgi bulunmamaktadır. ${ }^{3}$ Nihad M. Çetin onun $819 / 1416$ ' da başka bir eser daha kaleme aldığını söylemektedir (ÇETİN, 1991, s. 433) fakat bu eserin

3 Nev'îzâde Atâyî (öl. 1045/1635)'nin Şakâyık Zeyli'nde biyografisi verilen Mutahhar'ın başka birisi olduğu kanaatindeyiz. Atâyî, onun herhangi bir eser yazdığına dair bilgi vermemektedir (DONUK, 2017, s. 1715). 
isminin ve mahiyetinin ne olduğu belirtilmemiştir. Bir de şair adına kayıtlı Miftâh-ı Edeb isimli, telif kaydı bulunmayan bir sözlük vardır. ${ }^{4}$

\subsection{Ravzatu'l-Evzân'ın biçim ve içeriği}

Ravzatu'l-Evzân iki bölümden oluşmaktadır: mukaddime ve evzân.

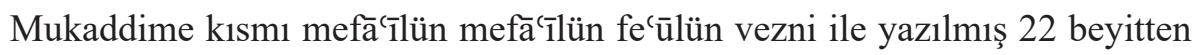
müteşekkildir. Bu kısımda hamdele, salvele ve sebeb-i teliften sonra aruz kalıplarını meydana getiren sekiz aslî rükün, fer'leri ve bahirleri hakkında bilgi verilmektedir. Buna göre sekiz aslî rüknün bir kısmı humâsî (beş harfli), bir kısmı ise subâî (yedi harfli)dir. Bunlar fe'ūlün, făcilün, mefācî̀ün, müfăcaletün, müstef'ilün, mütefācilün, fācilātün ve mef'ūlātüdür. Fer'leri ile birlikte bu rükünler 16 bahri oluşturmaktadır. Acem şairleri bunlara on bahir daha eklemişler, böylece 26 bahir meydana gelmiştir.

Görüldüğü gibi Mutahhar eserini klasik eser tertibine uygun şekilde meydana getirmiştir.

Eserin adı ve kim için yazıldığı yine bu kısımda belirtilmektedir:

kitābum ravżatu'l-evzān-1lan ad

èdindi k'işiden kişi olur şād

muhallaṣ adın'ètdüm ol begüy kim

yüz urısar öninde yẻdi iḳlīm

beg-i beg-zādedür ol ḥūr-peyker

ay $u$ günden anuy yüzidür enver

adınadur kitābum muștafānuy

kim adaşıdur ol ehl-i șafānuy

anı hak èrgüre şa'llah murāda

kim ola ehli ol şāh-1 murāda (18-22. beyitler)

4 Bosna-Hersek Gazi Hüsrev Paşa Kütüphanesi R-2051/6 numarada kayıtlı mecmuanın 165 yer alan eser Kütüphane kataloğuna göre Farsça'dan Türkçe'ye bir sözlüktür. Şair hakkında ise maalesef hiçbir bilgi verilmemiştir. (POPARA, Haso; FAJIC, Zejnil, 2000, s. 330) N. M. Çetin belki de bu sözlüğü kasdediyordu, ancak teyit etme imkanımız olmadı. Süleymaniye Kütüphanesi Şazeli Tekkesi nr. 147'de bir nüshası bulunan Ravzatu'l-Evzân'ın devamında Arapça-Farsça gramer ve sözlükten oluşan bir kısım bulunmaktadır. Başlıksız olan bu kısım Miftâh-ı Edeb'in ikinci nüshası olabilir. 
Yukarıdaki beyitlere göre eserin adı Ravzatu'l-Evzân olup Mustafa Bey adına kaleme alınmıştır. 22. beyitteki "şâh-1 murâd" ifadesi Sultan II. Murad (saltanatı: 824-855/1421-1451)'ı işaret ediyor olmalıdır. Şairin "beg-i begzâdedür" dediği Mustafa Bey Karamanoğlu II. Mehmed Bey (öl. 826/1423)'in oğlu olabilir. Mustafa Bey Dulkadırlılarla 1421 yılı civarında yapılan savaşta ölmüş, Mehmed Bey de bu savaşta esir düşmüştür. (SÜMER, 2001, s. 458) Şairin Lârendeli (Karaman) olması dolayısıyla Mustafa Bey'le bir şekilde irtibata geçerek eserini ona takdim etmeyi istediği düşünülebilir. Böylece 819/1416'da hayatta olduğunu bildiğimiz (ÇETİN, 1991, s. 433) Mutahhar'1n bu eserini 824/1421'de yazdığını söylememiz mümkündür.

İkinci kısımda aruz vezinleri anlatılmaktadır. Aruz konulu eserlerde yaygın bir uygulama olarak gördüğümüz kıt'alar hâlinde düzenlenmiş bu k1sımdaki her şiir, konu edindiği vezinle yazılmıştır. Burada toplamda 24 vezin anlatılmaktadır.

Şairin adı yine bu bölümdeki 2, 7, ve 11. kıt'alarda "Muțahhar" olarak geçmektedir. Eserin her iki yazma nüshasında da hâtime bölümü bulunmamaktadır; eser eksik bir biçimde veya mevcut bölümü seçilerek istinsah edilmiş olabilir.

\subsection{Ravzatu'l-Evzân'daki vezinler}

Ravzatu'l-Evzân'daki vezinler Ahmedî, Ahmed-i Dâ'î, Alî b. Hüseyn-i Amâsî, Bardahî, Nevâyî (öl. 906/1501), Nazmî (öl. 967/1559'dan sonra), Sürûrî ve Aşkî’nin eserleriyle karşılaştırılmıştır. Benzerlik ve farklılıklar aşağıdaki tabloda birlikte verilmektedir: 


\begin{tabular}{|c|c|}
\hline \multicolumn{2}{|c|}{ 1. baḥr-ı serī'-i mațvī / baḥr-ı recez-i mațvī müftecilün müftecilün fâcilün } \\
\hline Ahmed-i Dâ'î & bahr-1 müseddes-i matvî: müftecilün müftecilün fâcilün \\
\hline Amâsî & bahr-1 serî‘-i matvî: müftecilün müftecilün fâcilün \\
\hline Bardahî & bahr-1 serî‘-i matvî: müftecilün müftecilün fâcilün \\
\hline Nevâyî & bahr-1 serî́-i matvî-yi mekşûf: müfte'ilün müfte'ilün fâcilün \\
\hline Nazmî & $\begin{array}{l}\text { bahr-1 serî'-i matvî vü 'arûz u darb-1 eşter: müfte'ilün müftecilün } \\
\text { fấcilün }\end{array}$ \\
\hline Sürûrî & bahr-1 recez-i matvî-yi merfû́: müftecilün müftecilün fâcilün \\
\hline Aşkî & $\begin{array}{l}\text { bahr-1 ser̂̂‘-i matvî-yi mekşûf: müftecilün müftecilün fâcilün } \\
\text { bahr-1 ser̂̂'-i matvî-yi mevkûf: müftecilün müftecilün fấilât } \\
\text { bahr-1 recez-i müzâl: müftecilün müftecilün fâcilân }\end{array}$ \\
\hline \multicolumn{2}{|c|}{ 2. baḥr-ı münseriḥ-i mațvī / baḥ̂-ı recez-i bā-ziḥāf u ḥaşv müftecilün fācilün müftecilün fac } \\
\hline Amâsî & bahr-1 münserih-i matvî: müftecilün făcilün müftecilün $\mathrm{fa}^{c}$ \\
\hline Bardahî & bahr-1 münserih-i matvî: müftecilün fắcilün müftecilün fac \\
\hline \multicolumn{2}{|c|}{ 3. baḥr-ı ḩafíf fā'ilātün mefācilün fecilün } \\
\hline Ahmed-i Dâ'î & bahr-1 hafîf-i müseddes: fācilātün mefācilün fe'ilün \\
\hline Amâsî & bahr-1 hafîf-i matvî: făcilātün mefā'ilün fecilün \\
\hline Nazmî & bahr-1 hafîf-i 'arûz u darb-1 mahzûf: făcilātün mefācilün fecilün \\
\hline Aşkî & bahr-1 hafîf-i müseddes: fācilātün mefācilün fe'ilün \\
\hline \multicolumn{2}{|c|}{ 4. baḥr-ı hafīf-i müntehab fā'ilān müfte'ilün fā'ilān müftecilün } \\
\hline Amâsî & bahr-1 hafîf-i müntehab: fầilâtü müftecilün fầilâtü müftecilün \\
\hline \multicolumn{2}{|c|}{ 5. baḥr-ı mużāric'i aḩreb mef'ūülü fā'ilātü mefāêìlü fā'ilün } \\
\hline Ahmed-i Dâ'î & bahr-1 muzâri'-i müsemmen-i ahreb: mef'ūlü făcilātü mefā̌c̄ilü făcilün \\
\hline Bardahî & bahr-1 muzârici ahreb: mef'ūlü făcilātü mefấc̄ilü făcilün \\
\hline Nevâyî & $\begin{array}{l}\text { bahr-1 muzâri'-i müsemmen-i ahreb-i mekfûf-1 mahzûf: mef'ūülü } \\
\text { fā'ilātü mefā'îlü fā'ilün }\end{array}$ \\
\hline Nazmî & $\begin{array}{l}\text { der-bahr-1 muzâri` sadr u ibtidâ ahreb ü haşv-1 mekfûf u 'arûz u darb } \\
\text { u harb mahzûf mef'ûlü fầ'ilâtü mefấîlü fầilün }\end{array}$ \\
\hline Aşkî & bahr-1 muzâric: mef'ûlü fâcilâtü mefâcîlü fầilün \\
\hline \multicolumn{2}{|c|}{ 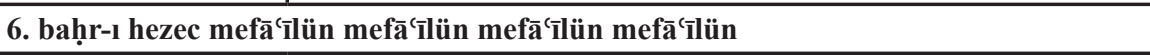 } \\
\hline Ahmedî & 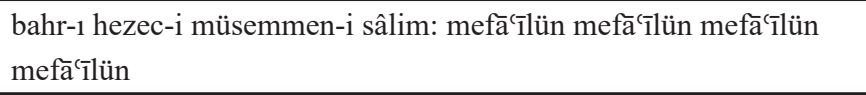 \\
\hline Ahmed-i Dâ'î & $\begin{array}{l}\text { bahr-1 hezec-i müsemmen-i sâlim: mefấîlün mefā'î̀ün mefấîlün } \\
\text { mefā'îllün }\end{array}$ \\
\hline
\end{tabular}




\begin{tabular}{|c|c|}
\hline Amâsî & 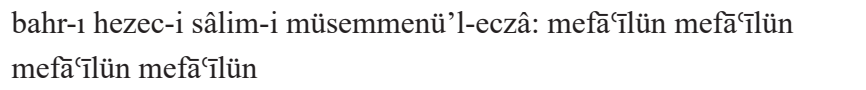 \\
\hline Bardahî & $\begin{array}{l}\text { bahr-1 hezec-i sâlim-i müsemmen: mefăcîlün mefă‘̂́lün mefăcîlün } \\
\text { mefācîlün }\end{array}$ \\
\hline Nevâyî & 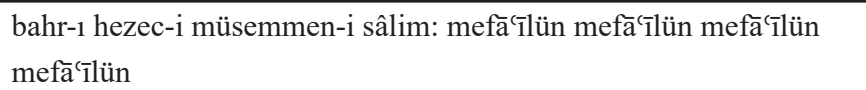 \\
\hline Nazmî & bahr-1 hezec-i sâlim: mefācîlün mefācîlün mefācîlün mefācîlün \\
\hline Sürûrî & bahr-1 hezec-i sâlim: mefācîllün mefācîlün mefācîllün mefācîllün \\
\hline Aşkî & bahr-1 hezec-i müsemmen-i sâlim: bahr-1 hezec-i müsemmen-i sâlim \\
\hline \multicolumn{2}{|c|}{ 7. hezec-i maḩzūf mefācīlün mefā'īlün fe'ūlün } \\
\hline Ahmed-i Dâ'î & bahr-1 hezec-i müseddes: mefâcîlün mefầîlün fe culün \\
\hline Amâsî & bahr-1 hezec-i mahzûf-1 müseddes: mefâ‘̂̂lün mefâcîlün fecûlün \\
\hline Bardahî & bahr-1 hezec-i mahzûf-1 müseddes: mefầîlün mefấ̂̂lün fecûlün \\
\hline Nevâyî & bahr-1 hezec-i müseddes-i mahzûf: mefầîlün mefâcîlün fecûlün \\
\hline Nazmî & $\begin{array}{l}\text { bahr-1 hezec-i müseddes 'arûz u darb-1 mahzûf: mefầîlün mefầîllün } \\
\text { fe'ûlün }\end{array}$ \\
\hline Sürûrî & bahr-1 hezec-i meczû'-i mahzûf: mefầîlün mefầîlün fe'ûlün \\
\hline Aşkî & bahr-1 hezec-i müseddes: mefâcîlün mefấîlün fecûlün \\
\hline \multicolumn{2}{|c|}{ 8. hezec-i müseddes mef'ūlü mefā'ilün fe'ūlün } \\
\hline Ahmed-i Dâ'î & bahr-1 hezec-i müseddes-i ahreb: mef'ûlü mefầilün fe'ûlün \\
\hline Amâsî & bahr-1 hezec-i müseddes: mef'ûlü mefâcilün fe'ûlün \\
\hline Bardahî & bahr-1 hezec-i müseddes-i makbûz: mef'ûlü mefâcilün fe'ûlün \\
\hline Nevâyî & $\begin{array}{l}\text { bahr-1 hezec-i müseddes-i ahreb-i makbûz-1 mahzûf: mef'ûlü } \\
\text { mefâcilün fe ûlün }\end{array}$ \\
\hline Nazmî & $\begin{array}{l}\text { bahr-1 hezec-i ahreb-i müseddes sadr u ibtidâ ahreb ü cüz' ü duv- } \\
\text { vum u pencum makbûz u 'arûz u darb-1 mahzûf: mef'ûlü mefâcilün } \\
\text { fe'ûlün }\end{array}$ \\
\hline Sürûrî & $\begin{array}{l}\text { bahr-1 hezec-i ahreb-i makbûz-1 mahzûf-1 meczû: mef'ûlü mefấcilün } \\
\text { fe'ûlün }\end{array}$ \\
\hline Aşkî & bahr-1 hezec-i muktedab: mef'ûlü mefâcilün fe'ûlün \\
\hline \multicolumn{2}{|c|}{ 9. baḥr-ı recez-i müșemmen müstef'ilün müstef'ilün müstef'ilün müstef'ilün } \\
\hline Ahmedî & $\begin{array}{l}\text { bahr-1 recez-i müsemmen-i sâlim: müstef'ilün müstef' }{ }^{\Upsilon} i l u ̈ n \\
\text { müstef }\end{array}$ \\
\hline Ahmed-i Dâ'î & $\begin{array}{l}\text { bahr-1 recez-i müsemmen-i sâlim: müstef'ilün müstef }{ }^{\Upsilon} i l u ̈ n \\
\text { müstef' } \\
\text { 'ilün müstef }{ }^{\prime} \text { ilün }\end{array}$ \\
\hline
\end{tabular}




\begin{tabular}{|c|c|}
\hline Amâsî & 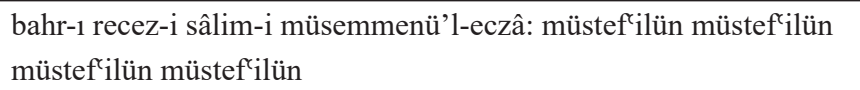 \\
\hline Bardahî & $\begin{array}{l}\text { bahr-1 recez-i sâlim-i müsemmen: müstef'ilün müstef'ilün } \\
\text { müstef'iliün müstef'ilün }\end{array}$ \\
\hline Nevâyî & 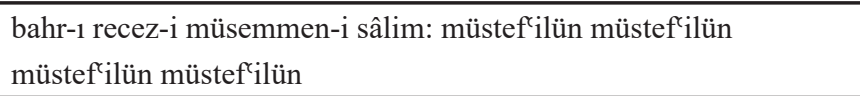 \\
\hline Nazmî & 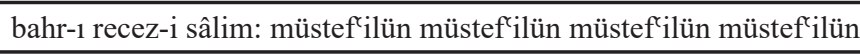 \\
\hline Sürûrî & 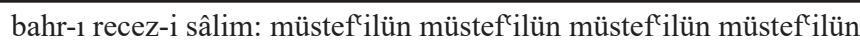 \\
\hline Aşkî & $\begin{array}{l}\text { bahr-1 recez-i müsemmen-i sâlim: müstef'ilün müstef'ilün } \\
\text { müstef'ilün müstef'ilün }\end{array}$ \\
\hline \multicolumn{2}{|c|}{ 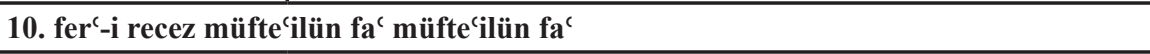 } \\
\hline \multicolumn{2}{|c|}{ 11. fer'-i recez fa' müfte'ilün müfte'ilün müftecilün fac } \\
\hline \multicolumn{2}{|c|}{ 12. fer'-i recez fa' müfte'ilün mefā'ilün fac } \\
\hline Amâsî & fer'-i recez: fa' müftecilün mefầilün $\mathrm{fa}^{c}$ \\
\hline Bardahî & fer'-i recez: fa' müftecilün mefầilün $\mathrm{fa}^{\mathrm{c}}$ \\
\hline Aşkî & muzârici tesmîn: $\mathrm{fa}^{\mathrm{c}}$ mütfecilün mefầilün $\mathrm{fa}^{\mathrm{c}}$ \\
\hline \multicolumn{2}{|c|}{ 13. recez-i sālim / basīt u hezec-i mülemma' müftecilün mefā'ilün müftecilün mefācilün } \\
\hline Ahmedî & $\begin{array}{l}\text { bahr-1 recez-i matvî-yi mahbûn: müftecilün mefầilün müftecilün } \\
\text { mefấcilün }\end{array}$ \\
\hline Amâsî & fer'-i bahr-1 medîd: müftecilün mefâcilün müftecilün mefấcilün \\
\hline Bardahî & $\begin{array}{l}\text { bahr-1 medîd-i müsemmen: müftecilün mefầcilün müftecilün } \\
\text { mefấilün }\end{array}$ \\
\hline Nevâyî & $\begin{array}{l}\text { recez-i müsemmen-i matvî-yi mahbûn: müftecilün mefâcilün } \\
\text { müftecilün mefâcilün }\end{array}$ \\
\hline Nazmî & $\begin{array}{l}\text { bahr-1 recez-i müsemmen cüz’î matvî ve cüz’î mahbûn: müftecilün } \\
\text { mefâcilün müftecilün mefâcilün }\end{array}$ \\
\hline Sürûrî & $\begin{array}{l}\text { bahr-1 recez-i matvî-yi mahbûn: müftecilün mefấcilün müftecilün } \\
\text { mefâcilün }\end{array}$ \\
\hline Aşkî & bahr-1 recez: müftecilün mefấcilün müftecilün mefầilün \\
\hline \multicolumn{2}{|c|}{ 14. baḥr-ı nev'-i āhar ez-recez-i ziḥāf fa' müfte'ilün fa'lün fa' müfte'ilün fa'lün } \\
\hline \multicolumn{2}{|c|}{ 15. baḥ̂r-ı vāfir müfā'aletün müfā'aletün müfā'aletün } \\
\hline Bardahî & bahr-1 vâfir: müfâ‘aletün müfâ'aletün müfấaletün \\
\hline Sürûrî & bahr-1 vâfir-i sâlim: müfâ‘aletün müfâ‘aletün müfâ‘aletün \\
\hline \multicolumn{2}{|c|}{ 16. baḥr-ı kāmil mütefā'ilün mütefā'ilün mütefā'ilün mütefā'ilün } \\
\hline Amâsî & $\begin{array}{l}\text { bahr-1 kâmil-i müsemmen: mütefâcilün mütefâcilün mütefâcilün } \\
\text { mütefầilün }\end{array}$ \\
\hline
\end{tabular}




\begin{tabular}{|c|c|}
\hline Bardahî & bahr-1 kâmil: mütefâcilün mütefâcilün mütefâcilün mütefâcilün \\
\hline Nevâyî & $\begin{array}{l}\text { bahr-1 kâmil-i müsemmen-i sâlim: mütefâcilün mütefâcilün } \\
\text { mütefấcilün mütefâcilün }\end{array}$ \\
\hline Nazmî & bahr-1 kâmil: mütefâcilün mütefâcilün mütefâcilün mütefâcilün \\
\hline Sürûrî & bahr-1 kâmil-i sâlim: mütefâcilün mütefâcilün mütefâcilün mütefấcilün \\
\hline Aşkî & $\begin{array}{l}\text { bahr-1 kâmil-i müsemmen-i sâlim: mütefầcilün mütefâcilün } \\
\text { mütefầilün mütefâcilün }\end{array}$ \\
\hline \multicolumn{2}{|c|}{ 17. fer'-i kāmil mütefā'ilün mütefā'ilün mütefā'iliün } \\
\hline Nazmî & bahr-1 kâmil-i müseddes: mütefâcilün mütefâcilün mütefâcilün \\
\hline Sürûrî & $\begin{array}{l}\text { bahr-1 kâmil-i meczû'-i mütevâzin: mütefầcilün mütefâcilün } \\
\text { mütefấcilün }\end{array}$ \\
\hline \multicolumn{2}{|c|}{ 18. fer'-i kāmil mütefācilün fe'ūlün mütefācilün fe'ūlün } \\
\hline Amâsî & bahr-1 kâmil-i mukattaf: mütefầcilün fecûlün mütefâcilün fecûlün \\
\hline Bardahî & bahr-1 kâmil-i mukattaf: mütefầilün fecûlün mütefâcilün fecûlün \\
\hline Aşkî & bahr-1 kâmil-i mukattaf: mütefầcilün fe'ûlün mütefâcilün fe'ûlün \\
\hline \multicolumn{2}{|c|}{ 19. baḥr-ı müteḳārib fe'ūlün fe'ūlün fe'ūlün fe'ūl } \\
\hline Ahmed-i Dâ'î & bahr-1 mütekârib-i mahzûf: fe'ûlün fe'ûlün fe'ûlün fe'ûl \\
\hline Amâsî & bahr-1 mütekârib-i maksûr: fe'ûlün fe'ûlün fe'ûlün fe'ûl \\
\hline Bardahî & bahr-1 mütekârib-i mahbûn: fe'ûlün fe' ûlün fe'ûlün fe'ûl \\
\hline Nevâyî & bahr-1 mütekârib-i müsemmen-i maksûr: fe'ûlün fe'ûlün fe'ûlün fecûl \\
\hline Nazmî & bahr-1 mütekârib 'arûz u darb-1 maksûr: fe'ûlün fe' ûlün fe'ûlün fe'ûl \\
\hline Aşkî & fer'-i dîger: fe'ûlün fe'ûlün fe'ûlün fe'ûl \\
\hline \multicolumn{2}{|c|}{ 20. baḥr-ı basīṭ müfte'ilün fācilün müftecilün fācilün } \\
\hline Ahmed-i Dâ'î & bahr-1 münserih-i müsemmen: müftecilün fâcilün müftecilün fâcilün \\
\hline Amâsî & bahr-1 münserih-i matvî-yi mekşûf: müftecilün fầilün müftecilün fấcilün \\
\hline Bardahî & $\begin{array}{l}\text { bahr-1 münserih-i matvî-yi mekşûf: müftecilün fầcilün müftecilün } \\
\text { fấcilün }\end{array}$ \\
\hline Nevâyî & $\begin{array}{l}\text { bahr-1 münserih-i matvî-yi mekşûf: müftecilün fấcilün müftecilün } \\
\text { fấcilün }\end{array}$ \\
\hline Nazmî & $\begin{array}{l}\text { bahr-1 münserih-i matvî 'arûz u darb-1 mahzûf: müftecilün fấcilün } \\
\text { müftecilün fầcilün }\end{array}$ \\
\hline Aşkî & $\begin{array}{l}\text { bahr-1 basît-1 matvî-yi sâlim: müftecilün fâcilün müftecilün fâcilün } \\
\text { bahr-1 münserih-i matvî-yi mekşûf: müftecilün fầcilün müftecilün fâcilün } \\
\text { bahr-1 müctess-i matvî-yi mahzûf: müftecilün fâcilün müftecilün } \\
\text { fâcilün } \\
\text { bahr-1 recez-i matvî-yi merfûc: müftecilün fâcilün müftecilün fâcilün }\end{array}$ \\
\hline
\end{tabular}




\begin{tabular}{|c|c|}
\hline \multicolumn{2}{|c|}{ 21. fer'-i basīt müstef'ilün fe'ūlün müstef'ilün fe'ūlün } \\
\hline Amâsî & fer-i basît: müstef'ilün fe'ûlün müstef'ilün fe'ûlün \\
\hline Bardahî & fer'-i basît: müstef'ilün fe'ûlün müstef'ilün fe'ûlün \\
\hline Nazmî & fer'-i basît: müstef'ilün fe'ûlün müstef'ilün fe'ûlün \\
\hline \multicolumn{2}{|c|}{ 22. baḥr-ı remel fācilātün fācilātün fā'ilātün fā'ilün } \\
\hline Ahmedî & $\begin{array}{l}\text { bahr-1 remel-i mahzûf-1 müsemmen: fâcilâtün fấcilâtün fâcilâtün } \\
\text { fấcilün }\end{array}$ \\
\hline Ahmed-i Dâ'î & bahr-1 remel-i müsemmen: fâcilâtün fâcilâtün fâcilâtün fâcilün \\
\hline Amâsî & $\begin{array}{l}\text { bahr-1 remel-i müsemmen-i sâlimü'l-eczâ: fầcilâtün fầcilâtün fấcilâtün } \\
\text { fầilün }\end{array}$ \\
\hline Bardahî & $\begin{array}{l}\text { bahr-1 remel-i müsemmen-i mahzûf: fâcilâtün fâcilâtün fầcilâtün } \\
\text { fầilün }\end{array}$ \\
\hline Nevâyî & remel-i müsemmen-i mahzûf: fâcilâtün fâcilâtün fầilâtün fâcilün \\
\hline Nazmî & $\begin{array}{l}\text { bahr-1 remel-i müsemmen 'arûz u darb-1 mahzûf: fâcilâtün fâcilâtün } \\
\text { fầilâtün fấcilün }\end{array}$ \\
\hline Sürûrî & bahr-1 remel-i mahzûf: fâcilatün fâcilatün fâcilâtün fâcilün \\
\hline \multicolumn{2}{|c|}{ 23. remel-i maḳṣūr fā'ilātün fā'ilātün fā'ilün } \\
\hline Amâsî & bahr-1 remel-i mahzûf: fâcilâtün fấilâtün fấilün \\
\hline Bardahî & bahr-1 remel-i mahzûf-1 müseddes: fầilâtün fấcilâtün fầilün \\
\hline Nazmî & $\begin{array}{l}\text { bahr-1 remel-i müseddes 'arûz u darb-1 mahzûf: fâcilâtün fâcilâtün } \\
\text { fầilün }\end{array}$ \\
\hline Sürûrî & bahr-1 remel-i meczû'-i mahzûf: fầilâtün fầilâtün fấilün \\
\hline Aşkî & bahr-1 remel: fâcilâtün fầilâtün fầilün \\
\hline \multicolumn{2}{|c|}{ 24. remel-i mahbūn fe'ilātün fe'ilātün fe'ilātün fe'ilün } \\
\hline Amâsî & $\begin{array}{l}\text { bahr-1 remel-i mahbûn-1 müsemmenü'l-eczâ: fe'ilâtün fecilâtün } \\
\text { fe'ilâtün fecilün }\end{array}$ \\
\hline Bardahî & $\begin{array}{l}\text { bahr-1 remel-i mahbûn-1 müsemmen: fe'ilātün fecilātün fecilātün } \\
\text { fe'ilün }\end{array}$ \\
\hline Nazmî & $\begin{array}{l}\text { bahr-1 remel-i müsemmen heme eczâ mahbûn u 'arûz u darb-1 } \\
\text { mahzûf: fe'ilâtün fe'ilâtün fe'ilâtün fe'ilün }\end{array}$ \\
\hline Aşkî & fer'-i dîger: fe'ilâtün fe'ilâtün fe'ilâtün fecilün \\
\hline
\end{tabular}




\section{Değerlendirme}

Tabloya göre; müfte 'ilün müfte 'ilün fầilün Mutahhar'da hem serî' hem de recez bahrindendir, karşılaştırdığımız diğer eserlerin bir kısmında serî’, bir kısmında ise recez bahrinden gösterilmektedir. Müfte'ilün fãcilün müftecilün $f a^{\prime}$ vezni Mutahhar'da hem münserih hem de recez bahrine dahil edilmiştir; diğer eserlerde ise münserih bahrindendir. Müfte'ilün $f a^{\prime}$ müfte ilün $f a^{\prime}$ ve $f a^{c}$ müfte ilün müftecilün müfte'ilün $f a^{`}$ vezinleri diğerlerinde bulunmamaktadır. Fa' müfte'ilün mefā'ilün fa'vezni Mutahhar'da recez bahrinden iken Aşkî' de muzâri' bahrinden sayılmıştır. Müfte'ilün mefācilün müfte 'ilün mefā'ilün vezni Mutahhar'a göre recez bahrinden olup ayn zamanda basît ve hezec bahrinin cüzlerinden oluşmuştur. Amâsî’ye göre medîd bahrinden olan vezin diğerlerinde hezec bahrine dahil edilmiştir. Fa' müfte'ilün fa 'lün fa' müfte 'ilün fa clün vezni diğer eserlerde bulunmamaktadır. Müftecilün fācilün müfte‘ilün fācilün vezni Mutahhar'da basît bahrindendir, diğerlerine göre ise münserih bahrine dahildir. Aşkî bu veznin fer'lerinin değişmesine bağlı olarak hem basît ve münserih hem de müctess ve recez bahirlerinden sayılabileceğini söyler. Mutahhar'ın zikrettiği vezinlerin çoğunda diğer eserlerdeki bilgilerle uyuştuğu söylenebilir.

\subsection{Ravzatu'l-Evzân' In nüshaları}

Ravzatu'l-Evzân'ın iki nüshasını tespit ettik. Bunlardan ilki Staatsbibliothek zu Berlin (Berlin Devlet Kütüphanesi)'de Ms. or. oct. 3744 numarada kayıtlı mecmuanın 147ª-152 yaprakları arasında "Risāle-yi 'Arūz ez-Güftār-1 Muțahhar” başlı̆̆ı ile yer almaktadır (çeviriyazılı metinde A kısaltması ile göstereceğiz). Eserin yaprakları cedvellidir. Cedveller çift çizgili olup içi altın suyu ile doldurulmuştur. Eserin başlıkları altın suyu ile, diğer kısımları siyah mürekkeple, tek sütun hâlinde nesih hatla yazılmıştır. Her sayfada dokuz satır bulunmaktadır. Sayfalar müşirlidir. İlaveten yapraklar Arap rakamlarıyla numaralandırılmıştır. 
Baş: çü bi-smi’'lāhi raḥmāni’r-raḥ̄mi diyẹsin bulasın raḥm-1 rahīmi

Son: $\quad$ müftecilün mefācilün müftecilün mefācilün rub'-1 basịța ėrişür rükn-ilen èy şeh-i ümem

Eserin ikinci nüshası Süleymaniye Kütüphanesi Şazeli Tekkesi Bölümü 147 numarada kayıtlı mecmuanın 187a-189a yaprakları arasında "Āḡāz-1 Kitāb-1 'Arūz ez-Güftār-1 Faḳīr Muțahhar” başlığı ile yer almıştır (çeviriyazılı metinde $\mathrm{S}$ kısaltması ile göstereceğiz). Eserin bulunduğu kısımdaki yapraklar cedvelsizdir. Başlıklar kırmızı mürekkeple, diğer kısımlar siyah mürekkeple nesih hatla, çift sütun hâlinde yazılmıştır. Mısralardaki med, vasl, kasr gibi aruz uygulamaları mısra altlarında kırmızı mürekkeple yazılarak gösterilmiştir. Her sayfada 22 satır vardır. Sayfalarda müşir yoktur ancak hem Arap hem de Hind rakamları ile sayfalar numaralandırılmıştır. Son sayfada Arap edebiyatına özgü on altı bahir beş daire hâlinde verilmiştir.

Baş: çü bi-smi'llāhi raḥmāni’r-raḥimi diyẹsin bulasın raḥm-1 rahīmi

Son: müftecilün mefācilün müftecilün mefācilün rub`-1 basìța èrişür rükninün èy şeh-i ümem

\section{İşaretler ve Kısaltmalar}

\begin{tabular}{|l|l|}
\hline$<$ & geliş yönünü gösterir \\
\hline() & metinden elde edilerek eklenen bölüm \\
\hline$[\ldots]$ & tahmini olarak eklenen bölüm \\
\hline$[=]$ & diliçi çeviri \\
\hline A & $\begin{array}{l}\text { Staatsbibliothek zu Berlin (Berlin Devlet Kütüphanesi), Ms. or. oct. 3744, vr. } \\
147^{\mathrm{a}}-152^{\mathrm{b}}\end{array}$ \\
\hline S & Süleymaniye Kütüphanesi Şazeli Tekkesi Bölümü nr. 147, 187ª $-189^{\text {a }}$ \\
\hline ẹ & çeviriyazıda Türkçe kelimelerde iç seste elifle yazılan açık e \\
\hline$\dot{e}$ & çeviriyazıda Türkçe kelimelerde yâ ile yazılan kapalı e \\
\hline vr. & varak \\
\hline
\end{tabular}




\section{2. Çeviriyazılı Metin}

\section{A 147 a risāle-yi 'arūz ez-güftār-ı muțahhar

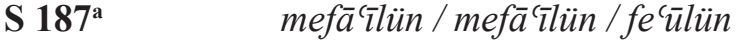 \\ hezec: + - - - / + - - / + _ - \\ 1 çü bi-smi'llāhi raḥmāni'r-rahịmi \\ diyẹsin bulasın raḥm-1 raḥīmi \\ 2 dilüne tanrı şükrin iş èdersen \\ cānuya ḥamdın anuy işidersen}

A $147^{\text {b }} 3$

nebīye șıdḳ ile dèrsey dürūdı

īmānuydan bulasın hayr sūdı

4

sözün vezni nedür bilmek dilersen

buhūrr-1 şi'ri sen yüzmek dilersen

5

gider göyülde ḳoma dahı teşvīş

sözünüy veznini key eyle teftīş

6

'arūżì şi rrlerden bir kaç ebyāt

öyünde țut söz anunl'eyle is bāt

7

sekiz rükni eger şi rïnje bünyād

A 148

èdersen țab'un olmaz şi'rden yād

sekiz rükn oldı lā-büd iki dürli

bile bilürsen olur şi'r dürli

\footnotetext{
* [= Mutahhar'ın Sözlerinden Aruz Risalesi]

1 [= Bismillâhi'r-rahmâni'r-rahîmi dersen çok acıyan (Tanrı'nın) acımısına kavuşursun.]

2 [= Tanrının şükrünü dilinin işi edersen, O'nun övgüsünü gönlüne işitdirirsen,]

3 dèrsey: èdersen $\mathrm{A}, \mathrm{S}$

[= Hz. Muhammed'e doğrulukla selam edersen imanından dolayı iyi bir kazanç elde edersin.]

4 yüzmek: yüzüp $S$

[= Sözün vezninin ne olduğunu bilmek istersen, şiir denizinde yüzmek istersen,]

5 teftīş: teşvīş A

[= gönlünde karışıklığı gider, sözünün ölçüsünü iyi incele.]

6 şi rrlerden: şi r'rden $\mathrm{S}$

[= Aruzlu şiirlerden birkaç beyti önünde tut, sözü onunla ispat et.]

7 [= Şiirine sekiz rüknü (kökü) temel edersen kişiliğin şiire yabancı olmaz.]

8 [= Sekiz rükün şüphesiz iki kısımdır, bilebilirsen şiir incili olur.]
} 
9

$\begin{array}{rr}\mathbf{A ~ 1 4 8} & 12 \\ & 13 \\ & 14 \\ & 15 \\ & \\ 16\end{array}$

16

A 149

15 humāāīdür birisi ḳıl ḳıyāsı

subā̄īiür biri cehli ḳoyası

fecūlün făcilündür ol humāāsi

ḳalan rükni subāç̄ide uması

mefā̄î̀ün müfā'altün sübāç̄

dahı müstef ${ }^{\prime} i$ ün gelmez rubā̄ $\overline{1}$

dahıı mütfācilün hem fācilātün

çü mef'ūlātü erkān oldı bütün

13 fürū'1 çoḳ-durur bu sekiz aṣlū

ajılursa olur tațvīli faṣlun

14 bu sekiz așla on altı buhūrı

çıkardılar ki dünyā țoldı nūrı

'arab şi'rinde bir ḳaç baḥrı zīrek

sakị̂l ola dėdiler eyledüm terk

'acem fāż̀lları ḳılmışlar efzūn

bu on altiya hem on baḥr-1 mevzūn

9 [= Birisi beş harflidir, anla; biri de yedi harflidir, cehaleti bırak.]

[= O beş harfli olan fe'ûlün ve fấcilündür, geriye kalan kökü yedi harfliden umabilirsin.] Arapça yazılışa göre fe'ûlün (F-c-V-L-N), fầcilün (F-A-'-L-N) beş harften oluşur.

10 [= $\mathrm{O}$ beş harfli olan fe'ûlün ve fấcilündür, geriye kalan kökü yedi harfliden umabilirsin.] Arapça yazılışa göre fecûlün (F-'-V-L-N), fấcilün (F-A-'-L-N) beș harften olușur.

11 müfấaltün: müfấiletün $\mathrm{A}$. Müfâ‘aletün kastediliyor.

[= Mefấîlün ile müfâ'aletün ve müstef'cilün yedi harflidir, dört harfli olmaz.] Mefâcîlün (M-F-A-`-Y-L-N), müfâcaletün (M-F-A-'-L-T-N) ve müstef'ilün (M-S-T-F-'-L-N) yedi harften oluşmaktadır.

12 Mütfâcilün ile mütefầilün kastediliyor.

[=Yine mütefấcilün ve fấcilâtün mef'ûlâtü gibi hepsi (aslî) köklerden oldu.] Mütefấcilün (M-T-F-A-'-L-N), fấcilâtün (F-A-'-L-A-T-N) ve mef'ûlâtü (M-F-'-V-L-A-T) yedi harflidir.

13 [= Bu sekiz rüknün fer'leri (dalları) çoktur, söylenirse bölüm/vakit uzar.]

14 așla: așlında S

[= bu sekiz kökten on altı bahir çıkardılar, onun ışığıyla dünya doldu.] Sekiz kökle dallarından bahirler olușturulmuş tur. Arap şiirindeki on altı bahir şunlardır: Tavîl [= Uzun], Medîd [= Uzatılmış], Basît [= Düz], Vâfir [= Bol], Kâmil [= Bütün], Hezec [= Türkü], Recez [= Titrek], Remel [= Koşma], Münserih [= Akıc1], Muzâri` [= Benzer], Muktedab [= Kesilmiş], Müctess [= Kopuk], Serî‘ $[=$ Çabuk], Hafîf [= Yeğni], Mütekârib [= Yakın] ve Mütedârik [= Ardışık] (ERASLAN, 1993, s. 181).

15 zīrek: zeyrek A, dèdiler: dile pes S, eyledüm: eyledük S

[= Bazı ehil kimseler Arap şiirinde birkaç bahir ağır/usandırıcı olur dediler, onları terk ettim.]

16 [= İran bilginleri bu on altı bahre on bahir eklemişler.] İranlı bilginlerin eklediği bahirlerden dördü Cedîd (Garîb)

[= Yeni], Müşâkil [= Benzeyen], Karîb [= Yakın] ve Sakîl [= Ağır]'dir (ERASLAN, 1993, s. 131). 
ḳamunuy èdeyüm bir bir beyānın

k'işiden kişinün şād ède cānın

kitābum ravżatu'l-evzān-1lan ad

èdindi k'işiden kişi olur şād

muhallaṣ adın'ètdüm ol begün kim

yüz urısar öyinde yẻdi iḳlīm

beg-i beg-zādedür ol ḥūr-peyker

ay $u$ günden anuy yüzidür enver

A 149

adınadur kitābum mușțafānun

kim adaşıdur ol ehl-i șafānuy

22

anı ḥaḳ èrgüre şa'llah murāda

kim ola ehli ol şāh-1 murāda

S 187

āġāz-ı risāle-yi mežkūr ${ }^{*}$

baḥr-ı serī'-i mațvī

mațvī serī' ister isen èy veled

rükni anuy oldı müseddes hasşed

17 [= Hepsini bir bir açıklayayım, böylece işiten kişinin içi açılsın.]

18 [= Kitabım, Ravzatu'l-Evzân "Vezinlerin Bahçesi” diye isimlendirildi, böylece işiten kişi sevinir.]

19 muhallaṣ: taḩalluṣ $\mathrm{S}$

[= (Kitabımı) yedi iklimin yüzünü önünde yere sürdüğü o korunmuş beyin adına yazdım.] Bir coğrafya terimi olup yedi iklim ekvatorun kuzeyinde kalan yedi bölgeyi (kişver) ifade eder. Bu yedi bölge Farslılara göre Hind, Arabistan, Çin, İran, Afrika, Türk, Rum (Roma)'dur; (AK, 2000, s. 28).

20 yüzidür: adıdur $\mathrm{A}$

[= O huri yüzlü beyoğlu beydir, onun yüzü ay ve günden parlaktır.]

21 [= Kitabım Mustafa Bey'in adınadır, o tertemiz olan (Hz. Muhammed'in) adaşıdır.]

22 kim ola ehli: k'ola tedbīr S, ol şāh-1 murāda: S-

[= Allah onu inşallah muradına erdirir, böylece o Sultan Murad'a ehil olur.]

* S'de başlık kırmızı mürekkeple buraya yazılmıştır: āgāaz-1 kitāb-1 'arūz ez-güftār-1 faḳīr muțahhar S.

1 Birinci bendin son mısraindan 14. bende kadarki bölüm A'da yoktur.

haşed: hased A, S

[= Ey oğul, serî bahrinin matvîsini sorarsan onun rüknü altılı olarak bir araya geldi. Müfte'ilün müftecilün fầilün; bir de sen diz, beni kıskanma.] Veznin altı parçadan (tef'ile/cüz') oluşması bu vezinle yazılan beytin mısralarındaki her bir cüzün sayılmasındandır. Matvî [= kıvrım, büküm] "tayy zihafına [= harf düşmesi] uğramış" manasındadır. Aruzda müstef ${ }^{\mathrm{i} i \text { ün }}$ kökünün kısaltılarak müste'ilün olması, onun yerine de müfte'ilün konulmasıdır. Yani müstef'ilün tayy zihafina uğrayarak müftecilün olmuştur. Yine veznin ikinci cüzü olan fấcilün, mef'ûlâtü kökünden tayy ve keşf kısalmasına uğrayarak mekşûf [= bükük] adını alır. Buna göre veznin adı bahr-1 serî‘-i müseddes-i matvî-yi mekşûfdur (ERASLAN, 1993, s. 122, 169). Vezin 188ada recez-i matvî başlı̆̆ı ile yeniden yazılmıştır:

mațvī recez bu-durur eyle nişān

ko lafunı ḳl șadef-i dür-nişān

müfte ilün müftéilün fã ilün

'ilm-i 'arüżı bilesin bī-gümān 
müftecilün müftecilün fācilün

A 150

bir dahı sen düz baya ḳılma ḥased

baḥr-ı münseriḥ-i maṭvī

2

münserih-i mațvīdür beyt ḳıl ez-ber

cilm-ile sen zāâtunı eyle mu'aț̣ar

müftecilün fācilün müftecilün $\mathrm{fa}^{c}$

șan'at-1la tuhfesin șundı muțahhar

\section{baḥr-ı hafîf}

3 cilm ögren dèyür hafîd-i becāl

baḥr gör āb-1 cilmi dilde zülāl

făcilātün mefăcilün fecilün

hııffet-i rūḥ lezzzet-i selsāl

S 187 bạ̣r-ı hafifif-i müntehab

4 bu hafîf müntehabuy vezn-i hūb-müntehabı

fâcilān müftecilün făcilān müftecilün

baḥr-1 mużārici aḩreb

5 işit mużāric ahrebi èderisen țaleb

olma melūl-i cehl ü bu cilm-ile ḳıl țarab

mef'ūülü fā'ilātü mefācî̀lü fā'ilün

'ilm-i 'arūżı bilmege bunlar olur sebeb

\footnotetext{
2 A-

[= Matvî münserih vezninde olan bu beyti ezberle; kendini sen ilmin güzel kokusuyla kokulandır. Müftecilün fâcilün müfte'ilün fa'; Mutahhar, sanatla armağanını sundu.] Vezin "recez-i bā-ziḥāf u ḥaşv" başlığı ile (S 188a) yeniden yazılmıştır:

yine recezle zihăf haşv nigārā

yār eger ögrene yaraya sara

müftéilün fāi ilün müfte ilün $f a^{\varsigma}$

'ilm-ile ḳl cehldür dène müdāvā

3 A-, baḥr: cehl S. Fe'ilün, fe'ilān olmalıydı.

[= Saygın yeğen ilim öğren diyor; ilmin suyunu/feyzini gönülde tatlı bir deniz bil, fâcilâtün mefâcilün fecilün; o ruh canlılığı ve saf suyun tadıdır.]

4 A-, müntehabı: müntehabin $\mathrm{S}$.

[= Bu hafîf seçkinin güzel seçilmiş vezni făcilān müftecilün fācilān müftecilün'dür.]

5 A-

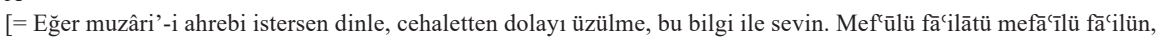
bunlar aruz ilmini bilmeye sebeptir.]
} 


\section{baḥr-1 hezec-i (müșemmen-i sālim)}

muțahhar şicri èt gönülde muḥkem

k’ola żihnüy șafiyy ü țab` mülhem

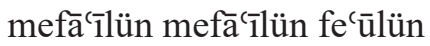

hezec mahžūfdur allāhu a'lem

hezec-i müseddes-i (mațvī)

bu bahrr-1 müseddes-i hezecdür

er olana cehl key haracdur

mef ${ }^{f}$ ūlü mefấîlün fe'ūlün

mațvīdür rükni şeş derecdür

\section{baḥr-ı recez-i müșemmen-i (sālim)}

baḥr-1 recezdür kim bunuy rükni müsemmendür yaḳīn cehl ètmesün saya eser bi'llāh sen seni saḳın

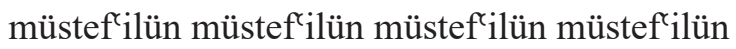
sālim recez işbu-durur 'ayne'l-yaḳ̄n ‘ilme'l-yaḳin

6 A-. Mefầīilün, mefāçìlān olmalıydı.

[= Rüknü sekizli olunca hezece sâlim denir. Çünkü onun aslından düşürülmüş olanı yoktur, ona böyle bina kur.

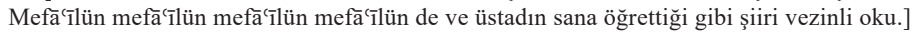

7 A-

[= Ey Mutahhar/Temiz şiiri gönlünde sağlam tut, böylece zihnin temiz olsun ve tabiatın ilham alsın. Mefāçîun mefăç̄lün fe'culün hezec-i mahzûfdur, en iyisini Allah bilir.]

$8 \quad$ A-, mef'ūlü: mef'ūlün $\mathrm{S}$

[= Bu hezec-i müseddes bahridir, yiğit olana cehalet ağır bir vergidir. Mef'ūlü mefācilün fecūlün, matvîdir, temeli altı rükündür (müseddestir).] Bu vezin aynı zamanda sekt-i melih veznidir, nitekim son mısrada sekt-i melih yapılarak vezin, mef'ūlün fā'ilün fecēlün olmuştur.

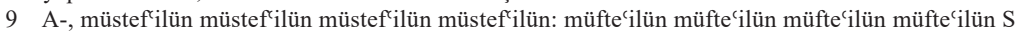
[= Recez bahrinin temeli sekizlidir, iyi anla; cehalet seni etkilemesin, billahi sen seni sakın. Müstef ${ }^{\mathrm{r} i l u ̈ n}$ müstef ${ }^{\mathrm{f} i l u ̈ n}$ müstef ${ }^{\Upsilon} i$ ün müstef ${ }^{\Upsilon} i$ ïn, kesin bilgi olarak salim recez işte budur.] 


\section{fer'-i recez}

10

bahr-1 recezden fer'-durur bu

èy ki saya ḥaḳ vèrdi kerāmet

müftecilün fa' müftecilün fac

'ilm ü edeble eyle emāret

\section{fer'-i recez}

11 vezni 'acemī așlı recezden gelür ekser

‘ilm-ile tenüni ède gör cān-1 muṭahhar

S $188^{a}$ $\mathrm{fa}^{c}$ müftecilün müftecilün müftecilün $\mathrm{fa}^{c}$ cismüyi hüner cān èder ü cānuyı enver

\section{fer'-i recez-i (müsemmen-i maḩbūn)}

12 fer'in recezün yene işitgil

fikr eyle bu fende sen iş ètgil

$\mathrm{fa}^{c}$ müftecilün mefācilün $\mathrm{fa}^{c}$

maḩbūn-1 müsemmen uş eyitgil

\section{recez-i sālim}

13 bir dahı digle fer'i sen baḥr-1 recezden èy veled

șaḳ’n teḥassür èdüben eyleme kimseye ḥased

müftecilün mefācilün müftecilün mefācilün

șaḳlar-1sạ vażīfeni èrdi kemāl yed be-yed

\footnotetext{
$10 \mathrm{~A}-$

[= Recez bahrinin fer'i şudur: müfte'ilün fa' müfte'ilün $\mathrm{fa}^{`}$. Allah sana iyilik ettiğine göre ilim ve edeple emirlik et.] $11 \mathrm{~A}-$

[= Vezni Farslara aittir, aslı çoğunlukla recezden gelir. Bedenini ilimle tertemiz bir cana dönüştür. Fa` müfte'ilün müftecilün müftecilün fa'; hüner, cismini canlandırır, canı ise nurlandırır.] 12 A-

[= Recezin fer'ini yine işit; düşün, bu konuyu iş edin, fa` müfte'ilün mefā'ilün fac', işte sekizli mahbûnu söyle.] 13 A-

[= Ey oğul, sen recez bahrinin fer'ini bir kere daha dinle; sakın üzülerek kimseyi kıskanma. Müfte'ilün mefācilün müfte'ilün mefă'ilün, vazifeni korursan olgunluk el ele sana gelir.]
} 


\section{baḥr-ı nev'-i āḩar ez-recez-i ziḥāf-ı (mațvī)}

14

A $150^{\mathrm{b}}$

A 151 ${ }^{\mathrm{a}}$

16

17 yine recezüy fercin benden ḳulag ur dinle

bu ḥaşv-1 ziḥāf-1lan şerḥin dèyeyüm ayla

$\mathrm{fa}^{c}$ müftecilün faclün fa' müftecilün faclün

maṭī-durur ikki rükni key ède gör illā

baḥr-ı vāfir [-i müseddes-i sālim]

çü vāfir olur muḥiblerün istimāletleri

bilürler ü daḩı dürlü çoḳ istițā'atları

müfācaletün müfācaletün müfācaletün

buya èricek gelür dahı iftihāret'leri

\section{baḥr-ı kāmil-i (müsemmen)}

mütekāmil oldū-1sa bu gün bu cemāl-1lan beni ḳ̂l rehī șanemā bizi göricek niçün yaşasın yüzi ḳoyasın rehi

mütefācilün mütefācilün mütefācilün mütefācilün çü bu kāmil erkānı ki müsemmen olur budur şinevī şehī

\section{fer'-i kāmil-i [müseddes-i maḳṣūr]}

buya kāmil oḳuduy-ısa sen işit aṣlını

șanemā bizi göricek niçün yaşasın femi

mütefā'ilün mütefācilün mütefācilün

kemelen tevāfüri ḥaẓẓenā bi-mekārimī

14 baḥr-1 S-, ède gör: ėdüyüz, illā: A-

[= Yine kulak ver, recezin fer'ini benden dinle; bu zihaf haşvı ile şerh edeyim, anla. Fa' müftecilün faclün fac müfte'ilün fa'lün, iki rüknü (tef'ilesi) matvîdir, mutlaka hakkıyla yap.]

15 baḥr-1 S-, dürlü çoḳ: çoḳ dürlü A, S, muhiblerün: muhiblerdeki S, istimāletleri: istimāletler A, S, çoḳ: çoh S, istițā'atları: istițā'atlar A, S, müfā'aletün: +müfā'aletün A, èricek: èrgüricegin S, gelür: fikri+ S, iftihāretleri: iftihāretler $\mathrm{A}$, istihāretler $\mathrm{S}$

[= Sevenlerin avunmaları çok olur ve de pekçok katlanma yolunu bilirler. Müfā'aletün müfā'aletün müfā'aletün, buna erince övünmeye başlarlar.]

16 baḥr-1: fer'-i A, olduy: oldur kim A, 1sa: çün A, S, 1lan: 1la A, yüzi: yüri A, beni ḳıl: ḳıl beni A, S, ki: A-, olur budur: olupdur A, şinevī: yeşev S

[= Bugün bu yüz güzelliği ile kemale erdiysen beni kul edin, ey sanem, bizi görünce niçin yüzünü saklayasın, bu yolu bırak; mütefăcilün mütefācilün mütefā'ilün mütefācilün, bu kâmil tef'ilesi sekizli olur, anlayışlılık ve ustalık budur.]

17 oḳıduy-1sa: ohıduy-1sa S, sen: A-, așlını: aṣlumı S, ḥaẓzenā: hatafen A

[= Buna kâmil dediysen sen aslını işit, ey sanem, bizi görünce ağzını niçin kapayasın? Mütefācilün mütefăcilün mütefăcilün, cömertliklerle nasiplendik, olgunluğumuz artt1.] 


\section{fer'-i kāmil-i [müșemmen-i] (muḳațțaf)}

$\mathbf{S ~ 1 8 8}^{\text {b }} \quad 18 \quad$ buna kāmil-i muḳaț̣af dèdiler bunı bilenler

sen iş èt bilürden ögren bularuy esāmīsini

mütefācilün fecēülün mütefācilün fecēülün

bütün ol bu 'ilm-ilen tā ṣımaya cehālet seni

baḥr-ı müteḳārib-i (müsemmen-i) [maḳṣūr]

19 tekāāub sekiz rükni buldı uṣūl

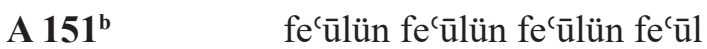

\section{baḥr-ı basīṭi (müșemmen-i) [maṭvī-yi sālim]}

20

baḥr-1 basịṭ̂ dèrem gözüni aç ü işit

rükni sekiz pāredür gönlüne anı iş èt

müftecilün fācilün müftecilün fācilün

ādemi ‘ālim olur cāhil-ile[n] birdür it

fer'-i basītei [müsemmen-i sālim]

21

fer'-i basīt old'adı bunun èy nigāre

cehd èdüp ögrenürsen èrmez saya melāle

A 152 ${ }^{\mathrm{a}}$

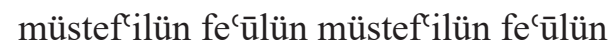

men cerrebe'l-mucerreb ḥallet bihi'n-nedāme

18 fer'-i kāmil: kāmil-i makțūn S, buna: bu A, muḳațtaf: mu'ațțaf A, cehālet: cühelā A

[= Bunu bilenler buna kâmil-i mukattaf dediler, bunların isimlerini sen bilenden öğren, iş edin; mütefăcilün feč̄ülün mütefācilün fe`ūlün, bu ilimle bütün ol, böylece cehalet seni kırmasın.]

19 rükni: rükn $\mathrm{A}$

[= Mütekârib bahri sekiz rükün (tef'ile) ile usul buldu, fecūlün fe'ūlün fecūlün fecūl.]

20 birdür it: berdār it $\mathrm{S}$

[= Bahr-1 basîti söyleyeyim, gözünü aç ve işit, rüknü sekiz parçadır, onu gönlüne iş et, müftecilün fācilün müftecilün fắcilün, insanı âlim olur, câhille it birdir.] Bahr-1 basît vezni Nevâyî'de (ERASLAN, 1993, s. 131) ve 'Alî b. Hüseyn-i Amâsî'de (COŞKUN, 2003, s. 128) müstef'ilün fā'ilün müstef'ilün fā'ilündür.

21 adı: çün $\mathrm{A}$

[= Ey nigâr, bunun adı fer '-i basît oldu, çalıșıp öğrenirsen sana üzüntü ulaşmaz; müstef'ilün fe'ūlün müstef'ilün fe'ūlün, denenmiş olanı deneyen pişmanlıkla karşılaşır.] 


\section{baḥr-1 remel-i (müsemmen-i) [maḩzūf]}

ad-1lan ana müsemmen dẻdiler bilgil șiḳāt

fācilātün făcilātün făcilātün făcilün

cehl zulmetdür èrişdür sen sana andan necāt

\section{remel-i (müseddes-i) makṣūr}

üç olıcak rükni ol maḳṣūr olur

A 152 ${ }^{\text {b }}$

cāhil olan ḩōr u hem maḳhūr olur

făcilātün fācilātün făcilün

(ālim olan hem-nişīni hūur olur

\section{remel-i [müșemmen-i] mahbūn}

remel-i maḩbūn-1lan şi'r bu gün āb-1 hayāt

oldı çün laclüne èrgürdi özini fecilāt

fecilātün fe'ilātün fecilātün fecilün

şi'ri bu vezn-ilen oḳursay olur lafẓ nebāt

S 189a

${ }^{25}$ dā' ire-yi evvel-rā muhtelife hู ${ }^{v a ̄ n e n d ~ v e ~ d e r-i ̄ n ~ d a ̄ ' i r e ~}$ bīst $u$ heşt harf muteḥarrik ve bīst ḥurūf sākin est țavīl fe'ūlun mefāî̀lun erba'a merrāt medīd făcilātun fācilun erba'a merrāt basīt mustef ilun făcilun erba'a merrāt

22 bu: A-, sebāt: necāt A, ad-1lan: ad-1la A, ana: S-, bilgil: buldı A, cehl-i: baḥr-1 A, èrişdürsin: işidirsen A [= Remel bahrı bu sekiz rükünle sabit olduğu için bilenler ona ad olarak müsemmen dediler, fācilātün fā'ilātün făcilātün făcilün, cehalet karanlıktır, sen sana ondan kurtuluş eriştir/sen seni kurtar.]

23 [= Rüknü üç olunca maksûr olur, cahil olan hem hor hem kahırlı olur. făcilātün făcíātün fācilün, âlim olanın arkadașı huri olur.]

24 bu gün: A-, èrgürdi özini: ögretdi A, ilen: ile A. Veznin son cüzü fecilān olmalıydı. [= Remel-i mahbûn ile şiir bugün ölümsüzlük pınarı olduğu için fe'ilât kendini senin dudağına eriştirdi. Fecilātün fe'ilātün fe'ilātün fe'ilün, şiiri bu vezinle okursan söz şeker olur.]

25 Bu kisım A'da yoktur.

[= Birinci daireye Muhtelife derler, yirmi sekiz harekeli harf ve yirmi sakin harftir. Tavîl, fe'ûlün mefâ'îlün, dört defa. Medîd, fâ'ilâtün fâ'ilün, dört defa. Basît, müstef'ilün fâ'ilün, dört defa.] 
muteḥarrik ve duvāz deh ḥarf sākin est

vāfir mufācaletun sitte merrāt

kāmil mutefācilun sitte merrāt

bīst u çehār ḥarf muteḥarrik ve heşt ḥarf sākin est

hezec mefā'cillun sitte merrāt

recez mustef'ilun sitte merrāt

remel fācilātun sitte merrāt

dā'ire-yi çehārum-rā muştebihe ḩ'ānend ve der-īn

dā'ire bīst u çehār ḥarf muteḥarrik ve heşt ḥarf sākin est

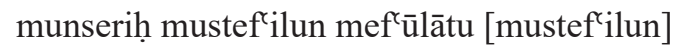

hafîf fācilātun mustef ${ }^{\mathrm{i}}$ ilun fācilātun

muctes $\underline{s}$ mustef'ilun fācilātun fācilātun

mużāric mefācīlun fācilātun mefā'c̄lun

muḳteḍab mef ${ }^{\Upsilon} \bar{u} l a ̄ t u ~ m u s t e f^{\Upsilon} i l u n ~ m u s t e f^{\Upsilon} i l u n$

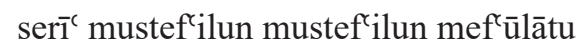

29

dā'ire-yi pencum-rā muttefiḳa gūyend ve der-īn

dā'ire bīst u çehār ḥarf muteḥarrik ve şāzdeh ḥarf sākin est

mutekāāib fecūlun semāne merrāt

mutedārik fācilun semāne merrāt

26 [= İkinci daireye Mü’telife derler, bu dairede otuz harf harekeli ve on iki harf sakindir. Vâfir, müfâ'aletün, altı defa. Kâmil, mütefâ'ilün, altı defa.]

27 [= Üçüncü daireye Müctelibe derler, bu dairede yirmi dört harekeli harf ve yirmi sakin harf vardır. Hezec, mefâ'îlün altı defa. Recez, müstef'îlün, altı defa. Remel, fâ'ilâtün, altı defa.]

28 [= Dördüncü daireye Müştebihe derler, bu dairede yirmi dört harf harekeli ve sekiz harf sakindir. Münserih, müstef'ilün mef'ûlâtü müstef'ilün. Hafîf, fâ'ilâtün müstef'ilün fâ'ilâtün. Müctes, müstef'ilün fâ'ilâtün fâ'ilâtün. Muzâri', mefâ'îlün fầilâtün mefâ'îlün. Muktedab, mef'ûlâtü müstef'ilün müstef'ilün. Serî', müstef'ilün müstef'ilün mef'ûlâtü.] Nevâyî'de müctes bahri müstef'ilün fâ'ilâtün mefâ'îlün olarak verilmiştir. (ERASLAN, 1993, s. 175)

29 [= Beşinci daireye Müttefika derler, bu dairede yirmi dört harf harekeli ve on altı harf sakindir. Mütekârib, fe'ûlün, sekiz defa. Mütedârik, fâ'ilün, sekiz defa.] 


\section{Sonuç;}

Mutahhar b. Ebî Tâlib, 14. yüzyılın sonu ile 15. yüzyılın başında yaşamış müelliflerdendir. Ravzatu'l-Evzân ve Miftâh-ı Edeb ile birlikte ismini ve mahiyetini bilemediğimiz bir eseri daha vardır. Ravzatu'l-Evzân muhtemelen 1421 'de Karamanoğlu Mustafa Bey'e sunulmak üzere kaleme alınmıştır. Yine bu küçük eser, Anadolu'da aruz konusunda Türkçe yazılmış ilk eserlerdendir. Eserde 24 aruz vezni ve bahirleri hakkında bilgi verilmektedir. Bu vezinlerin çoğu mukayese ettiğimiz aruz risâlelerinde de yer almakla birlikte bahir ve fer'leri ile alakalı farklı görüşler ihtiva edebilmektedir. 


\section{Kaynakça}

AK, M. (2000). İklim. TDV İslam Ansiklopedisi, 22, s. 28-30.

BELENKUYU, B. (2020). Türkçe Aruz Kaynakçası. Divan Edebiyatı Araştırmaları Dergisi-24, 137-172.

COŞKUN, M. (2003). Edebi Terimler ve Aruzla İlgili Bir Eser: Alî b. Hüseyin Hüsâmeddîn Amâsî'nin Risâletün mine'1-cArûz ve Istılâhi'ş-Şicr'i. Türk Kültürü İncelemeleri(8), 97-130.

ÇETIN, N. M. (1991). Arûz. TDV İslam Ansiklopedisi, 3, s. 424-437.

DONUK, S. (2017). Nevizâde Atâŷ̂'nin Şakâ'ik Zeyli: Hadâ'iku'l-Hakâ'ik fî-Tekmileti'şŞakâ'ik (İnceleme-Tenkitli Metin) (Cilt 2). İstanbul: Türkiye Yazma Eserler Kurumu Başkanlığı.

ERASLAN, K. (1993). Ali Şîr Nevâyî, Mîzânu'l-Evzân (Vezinlerin Terazisi). Ankara: Türk Dil Kurumu Yayınları.

MÜTERCIM ÂSIM EFENDİ. (2013). el-Okyânûsu'l-Basît fî-Tercemeti'l-Kâmûsi'l-Muhît Kâmûsu'l-Muhît Tercümesi (Cilt 3). (E. T. Mustafa Koç, Çev.) İstanbul: Türkiye Yazma Eserler Kurumu Başkanlı̆̆ı.

ÖZDEMIR, A. (2015). Aruz İlmi. İslâm Medeniyetinde Dil İlimleri Tarih ve Problemler (s. 357-424). içinde İstanbul: İSAM Yayınları.

POPARA, Haso; FAJIC, Zejnil. (2000). Gazi Husrev-Begova Biblioteka u Sarajevu Katalog Arapskih, Turskih, Rerzijskih, Bosanskih, Rukopisa, Svezak Sedmi, sv. 7. London: AlFurqan Islamic Heritage Foundation.

SEVGİ, A. (2007). Ahmed-i Dâî’nin Bilinmeyen Bir Eseri: İlm-i Arûz. Selçuk Üniversitesi Fen-Edebiyat Fakültesi Edebiyat Dergisi(18), s. 1-11.

SEVGİ, A. (2008). Ahmed-i Bardahî’nin Türkçe ve Farsça Manzum Aruz Risalesi. Selçuk Üniversitesi Fen-Edebiyat Fakültesi Edebiyat Dergisi(19), 37-55.

SÜMER, F. (2001). Karamanoğulları. DİA, 24, s. 454-460.

ŞAFAK, Y. (1991). Sürûrî'nin Bahrü'l-Ma'ârif'i ve Enîsü'l-Uşşâk ile Mukayesesi. Erzurum: Atatürk Üniversitesi, Dr. Tezi.

TAŞ, H. (2000). On Altıncı Yüzyıl Divan Şairlerinde Vezin Kullanımı. İstanbul: İstanbul Üniversitesi Sosyal Bilimler Enstitüsü, Yüksek Lisans Tezi.

ÜST, S. (2011). Edirneli Nazmî Dîvânı (İnceleme-Tenkitli Metin). Erzurum: Atatürk Üniversitesi, Dr. Tezi.

YAZAR, S. (2014). XVI. Yüzyılda Yazılmış Türkçe Bir Aruz Risalesi: Aşkî’nin Arûsu'lArûz'u. Dil ve Edebiyat Araştırmaları TDED(10), 83-130. 